\title{
МОДЕЛЮВАННЯ ТА ЕКСПЕРИМЕНТАЛЬНЕ ВИЗНАЧЕННЯ ХАРАКТЕРИСТИК ПНЕВМАТИЧНИХ ШИН ПРИ НАКОПИЧЕННІ ПОШКОДЖЕНЬ ВІД ДОРОЖНІХ ПЕРЕШКОД РІЗНОЇ ГЕОМЕТРІЇ
}

В статті наведено результати експериментальних вимірювань пружної деформації автомобільних иин 175/70 R13 при різних тисках на спеціальному стенді, щзо відтворює процеси накопичення механічних пошкоджень при подоланні дорожніх перешкод складної геометрії.

Отримані дані застосовано у новому методі оцінки проміжних станів матеріалу шин щуодо прогнозування механічних та експлуатаційних характеристик. Показано кінематичну поведінку колеса автомобіля на дорожньому покритті із визначеними механічними пошкодженнями $і$ властивостями 8 програмі Віброслой 1.

Пневматична шина забезпечує контакт транспортного засобу з дорожнім полотном, призначена для поглинання незначних коливань, викликаних недосконалістю дорожнього покриття, компенсації похибки траєкторій коліс, реалізації та сприйняття сил.

В лабораторних умовах та на випробувальному обладнанні перевіряється: конструктивна міцність пневматичних иин, якість гумових сумішей та інших матеріалів пневматичної шини, однорідність, жорсткістні і геометричні характеристики шин і багато іншого.

Методом математичного моделювання, адаптованим для розрахунку динамічних характеристик пневматичних шин, можна задавати будь-які комбінації деформування шини, вираховувати швидкість змін точок колеса як морфінг (перетикання) еластичної оболонки з одного стану в другий. Метод дозволяє в проиесі дослідження умов терміну служби шини отримати залежність від швидкості руху колеса та динамічного радіуса шини до иляху пройденого шиною до руйнування та детально спрогнозувати поведінку шини в цілому.

Розроблювана методика є альтернативою суто теоретичному визначенню реакцій колеса $і$ шини на різноманітні перешкоди в різних умовах руху автомобіля $і$ діі зовнішніх факторів . Державними стандартами $i$ технічними умовами різних краӥн-виробників передбачені критерії перевірки працездатності пневматичних шин. Деякі визначення для видів руйнування пневматичних шин стандартизовано.

Ключові слова: пневматична шина, моделювання, пошкодження, дорожня перешкода.

Д.А. ДМИТРИСВ

Херсонский национальный технический университет ORCID : 0000-0001-8200-351X

C.A. РУCAHOB

Херсонский национальный технический университет ORCID : 0000-0002-1003-4867

С.А. ЧУРСОВ

Херсонский национальный технический университет ORCID : 0000-0002-6746-530X

Е.Э. БЕРГЕР

Херсонський національний технічний університет ORCID : 0000-0002-5494-0247

\author{
МОДЕЛИРОВАНИЕ И ЭКСПЕРИМЕНТАЛЬНОЕ ОПРЕДЕЛЕНИЕ ХАРАКТЕРИСТИК \\ ПНЕВМАТИЧЕСКИХ ШИН ПРИ НАКОПЛЕНИИ ПОВРЕЖДЕНИЙ ОТ ДОРОЖНЫХ \\ ПРЕПЯТСТВИЙ РАЗЛИЧНОЙ ГЕОМЕТРИИ»
}


В статье приведены результать экспериментальных измерений упругой деформащии автомобильных шин 175/70 R13 при различных давлениях на специальном стенде, воспроизводящем проиессы накопления механических повреждений при преодолении дорожных препятствий сложной геометрии.

Полученные данные применены в новом методе оченки промежуточных состояний материала шин при прогнозировании механических и эксплуатационных характеристик. Показано кинематическое поведение колеса автомобиля на дорожном покрытии с определенными механическими повреждениями и свойствами в программе Виброслой 1.

Пневматическая шина обеспечивает контакт транспортного средства с дорожным полотном, предназначена для поглощения незначительных колебаний, вызванных несовершенством дорожного покрытия, компенсации погрешности траекторий колёс, реализации и восприятия сил.

В лабораторных условиях и на испытательном оборудовании проверяется: конструктивная прочность пневматических шин, качество резиновых смесей и других материалов пневматической иины, однородность, жесткостные и геометрические характеристики иин и многое другое.

Методом математического моделирования, адаптированным для расчета динамических характеристик пневматических иин, можно задавать любые комбинации деформирования иинь, высчитывать скорость изменений точек колеса таких как морфинг (перетькание) эластичной оболочки из одного состояния в другое. Позволяет в проиессе исследования условий срока службы шины получить зависимость от скорости движения колеса и динамического радиуса иинь в пути, пройденного шиной до разрушения, и подробно спрогнозировать поведение иины в целом.

Разрабатываемая методика является альтернативой чисто теоретическому определению реакиий колеса и шины на различные препятствия в различных условиях движения автомобиля и действия внешних факторов. Государственныли стандартами и техническими условиями различных стран-производителей предусмотрены критерии проверки работоспособности пневматических шин. Некоторые определения для видов разрушения пневматических иин стандартизировано.

Ключевые слова: пневматическая шина, моделирование, повреждения, дорожное препятствие

D.O. DMYTRIIEV

Kherson National Technical University ORCID : 0000-0001-8200-351X

S.A. RUSANOV

Kherson National Technical University ORCID : 0000-0002-1003-4867

S.O. CHURSOV

Kherson National Technical University ORCID : 0000-0002-6746-530X

E.E. BERHER

Kherson National Technical University ORCID : 0000-0002-5494-0247

\section{MODELING AND EXPERIMENTAL DETERMINATION OF THE CHARACTERISTICS OF PNEUMATIC TIRES IN THE ACCUMULATION OF DAMAGE FROM ROAD OBSTACLES OF DIFFERENT GEOMETRY}

The article presents the results of experimental measurements of elastic deformation of car tires 175/70 $R 13$ at different pressures on a special stand that reproduces the accumulation of mechanical damage in overcoming road obstacles of complex geometry.

The obtained data are applied in a new method of estimation of intermediate states of tire material concerning forecasting of mechanical and operational characteristics. The kinematic behavior of a car wheel on a road surface with certain mechanical damages and properties in the Vibrolayer 1 program is shown.

The pneumatic tire provides contact of the vehicle with a road surface, is intended for absorption of the insignificant fluctuations caused by imperfection of a road surface, compensation of an error of trajectories of wheels, realization and perception of forces.

In laboratory conditions, and on the test equipment it is checked: constructive durability of pneumatic tires, quality of rubber mixes and other materials of a pneumatic tire, homogeneity, rigid and geometrical characteristics of tires and many other things.

By the method of mathematical modeling adapted, for calculation of dynamic characteristics of pneumatic tires, it is possible to set any combinations of deformation of the tire, to calculate speed of changes of points of a wheel as morphing (crossing) of an elastic cover from one state to another. Allows in the process of research the conditions of tire life to obtain, depending on the speed of the wheel and the dynamic radius of the tire to the path traveled by the tire before failure, and to predict in detail the behavior of the tire. 
The developed technique is an alternative to a purely theoretical determination of the reactions of the wheel and tire to various obstacles in different conditions of the car and the action of external factors. State standards and technical conditions of different countries of manufacture provide criteria for checking the performance of pneumatic tires. Some definitions for types of pneumatic tire failure are standardized.

Key words: pneumatic tire, modeling, damage, road obstacle.

\section{Постановка проблеми}

Шина, яка забезпечуе контакт транспортного засобу з дорожнім полотном, призначена для поглинання незначних коливань, викликаних недосконалістю дорожнього покриття, компенсації похибки траєкторій коліс, реалізації та сприйняття сил [5-7].

Сучасні потужні САЕ-системи, не зважаючи на велику розповсюдженість, наявність різноманітних математичних методик для моделювання різних деформаційних процесів, допускають ряд обмежень та припущень і не враховують накопичену пошкоджуваність матеріалу, його анізотропію та ін. Тому послідовність імітування «Стендові випробування граничних станів - Моделювання проміжних станів» для автомобільних шин є актуальним для математичної моделі розрахунку та перспективним для оцінки працездатності, прохідності і безпеки руху автомобіля (рис.1) [9-10].

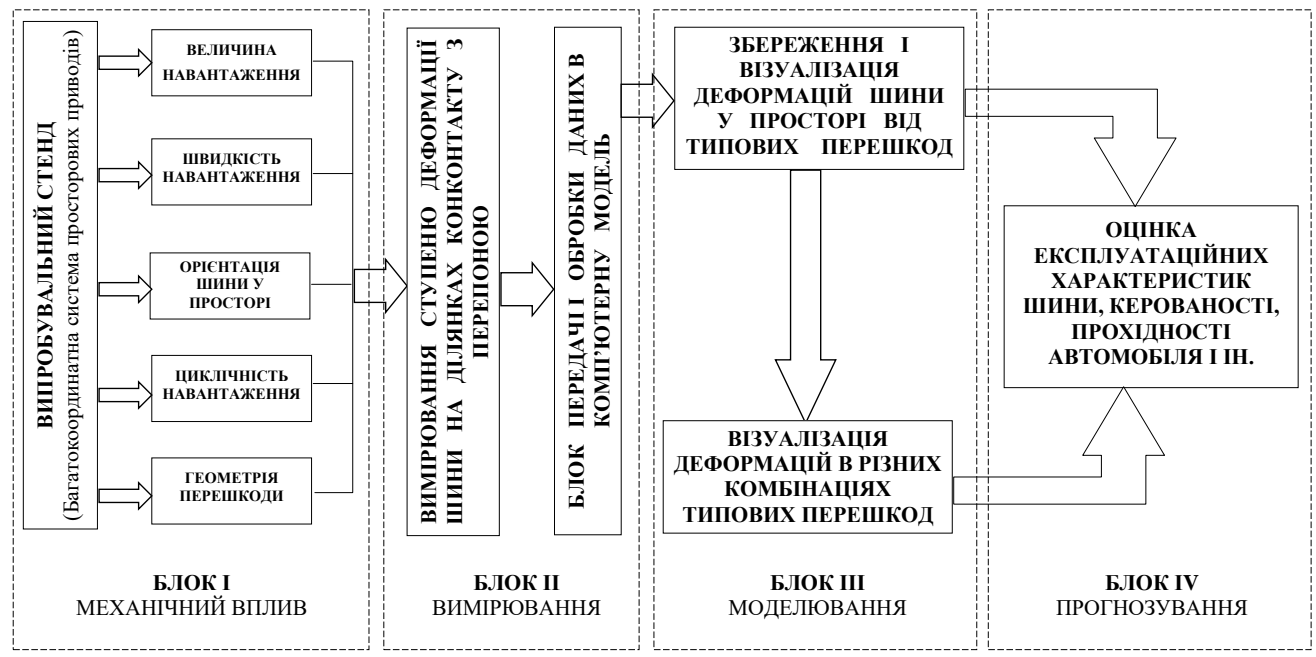

Рис. 1. Загальна блок схема оцінки накопичення експлуатаційних пошкоджень шин із застосуванням запропонованих технічних і програмних засобів

В свою чергу експериментальні методи контролю сучасної пневматичної шини об'єднують випробування на витривалість, опір на розшарування борту шини до ободу тощо. Значення основних критеріїв працездатності наведені ГОСТ4754-97:

- норми навантажень на шини для вибору режиму роботи при різних тисках;

- співвідношення між індексами та значеннями тиску;

- швидкості, застосовані при експлуатації шин, і відповідні їм індекси категорії швидкості;

- зміна індексу несучої здатності в залежності від швидкості шини;

- індекси несучої здатності;

- енергія руйнування.

\section{Формулювання мети дослідження}

Метою дослідження є моделювання механічних характеристик матеріалів пневматичних шин в процесі подолання перешкод для оцінки експлуатаційних характеристик пружних матеріалів; накопичення експериментальних даних для комп'ютерного моделювання щодо ступеню, форми просторової деформації дільниці шини, що контактує з перешкодою як застосування феноменологічного підходу прогнозування змін механічних властивостей матеріалу шин від ступеню накопичення механічних пошкоджень.

\section{Викладення основного матеріалу дослідження}

Для розробки математичної моделі розрахунку динаміки шини автомобіля треба розділити дві можливі обставини:

- динаміка з відривом від траси;

- динаміка з постійним контактом з трасою.

Для першого випадку критерієм відриву колеса від траси буде вважатися нульове значення реакції поверхні дорожнього полотна. Такі розрахунки потребують подвійного прогону циклу розрахункової моделі, для визначення значення реакції в даний момент часу, та істотного змінення алгоритму на тому ж 
кроці за часом при наявності відриву.

Умова відриву для горизонтальної поверхні траси може бути сформульована достатньо просто, а саме як перевищення відношення сил інерції до сил тяжіння значення одиниці, тобто необхідне контролювання комплексу $\underline{a}$, де $a$ - прискорення колеса, $\mathrm{g}$ - прискорення вільного падіння. Наприклад, g

якщо траса представляє собою хвилясту лінію, що апроксимується виразом $A \sin (w t)$, то комплекс буде мати вигляд $\frac{A \omega^{2}}{g}>1$.

Колесо повільно з'їжджає на перешкоду 3 невеликим відривом та 3 наступним утворенням коливань в самій шині (в цьому випадку ефекту підвіски не спостерігається та на колесо приходиться відповідна маса легковому автомобілю - даному випадку - 300 кг). Характерні важкопрохідні ділянки доріг можна характеризувати їх схематичними профілями. Ці схематичні профілі різні між собою та однозначно характеризують конкретну ділянку дороги. Але вони складаються 3 нечисельного набору елементів профілю, які наведені вже у формалізованому вигляді (табл. 1).

Таблиця 1

Аналітичне представлення формалізованих елементів типових ділянок дороги [4]

\begin{tabular}{|c|c|c|}
\hline $\begin{array}{l}\text { № } \\
\text { 3/п }\end{array}$ & $\begin{array}{l}\text { Формалізований елемент профілю типової } \\
\text { ділянки дороги }\end{array}$ & Вигляд аналітичного представлення \\
\hline 1 & 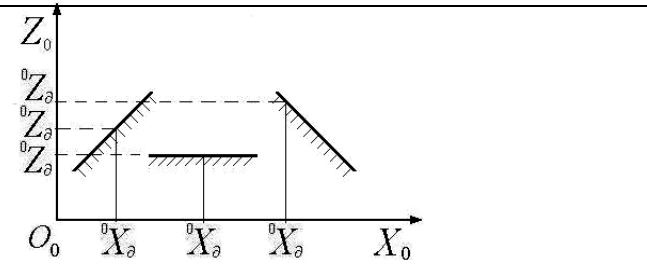 & ${ }^{0} Z_{d}=A \cdot{ }^{0} X_{d}+A_{0 ; A \underset{<}{>} 0 ;}^{>} A_{0} \neq 0$ \\
\hline 2 & $\begin{array}{lllll}Z_{0} & & & \\
& & & & \\
O_{0} Z_{\partial} & X_{2} & X_{2} & X_{2} & X_{0}\end{array}$ & $\begin{array}{l}{ }^{0} Z_{d}=\left\{\begin{array}{l}A \sin \left(a^{0} X_{d}\right) \\
A \mid \sin \left(a^{0} X_{d}\right)\end{array}\right. \\
A_{<}^{>} 0\end{array}$ \\
\hline 3 & $O_{0}^{{ }_{0}^{0} X_{2}} \stackrel{{ }^{0} X_{i \Pi}{ }^{0} X_{i K}}{Z_{0}}$ & $\begin{array}{l}{ }^{0} Z_{d}=\sum_{i=1}^{n} h_{i}\left[u_{+}\left({ }^{0} X_{d}-{ }^{0} X_{i \Pi}\right)-u_{+}\left({ }^{0} X_{d}-{ }^{0} X_{i K}\right)\right. \\
h_{i}<0 \\
{ }^{0} X_{i \Pi}<{ }^{0} X_{i K}\end{array}$ \\
\hline
\end{tabular}

Формалізовані елементи профілю типових ділянок доріг можна представити аналітично, використовуючи лінійні, тригонометричні, розривні функції з розривами першого роду. Таким чином математичний опис динаміки колеса буде в такому випадку аналогічний динаміці об'єкту на вібруючий поверхні. В цьому випадку ми можемо застосовувати спеціалізоване програмне забезпечення для моделювання об’єктів на вібруючих поверхнях. Прикладом може слугувати використання програмного забезпечення «Виброслой 1.0» [8], що створено саме для вказаних цілей - аналізу поведінки об'єктів 3 великою кількістю ступенів вільності (аж до сипучих середовищ поверхні дороги) на довільно переміщуваних поверхнях. Нижче представлено демонстрацію роботи в системі для моделювання поведінки колеса автомобіля шириною 20 см 3 масою 20 кг, що попадає в дорожню перешкоду вказаного нижче вигляду рухаючись 3 прискореннями, що формують рух 3 відривом (масу автомобілю не враховуємо вважаючи за наявний згладжуючий ефект підвіски).

Моделювати кінематику та динаміку відскоку колеса від нерівностей траси, можливо за допомогою спеціалізованих математичних пакетів програмних продуктів, у яких $\epsilon$ в наявності $\epsilon$ можливість розрахування контактних взаємодій між пружніми тілами. Програма підтримує розрахунки динаміки з урахуванням пружного контакту, для великої кількості тіл. Для повноцінного розрахунку 
необхідно правильно задати параметри жорсткості шини та підвіски автомобіля. Програма «Виброслой 1.0» підтримує також аеродинамічні характеристики (для представлених розрахунків аеродинамічними параметрами знехтувано). В результаті моделювання отримуємо параметри руху колеса у вигляді наступних графіків:

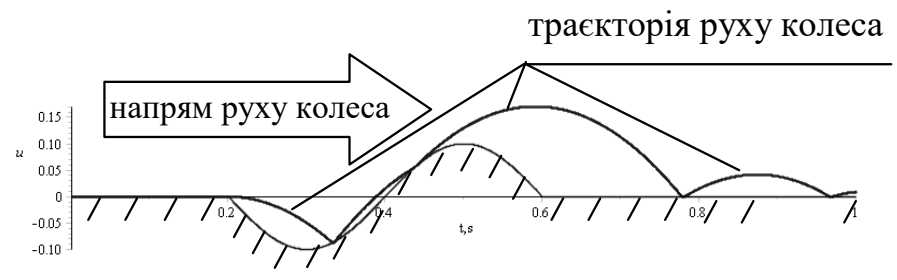

a)

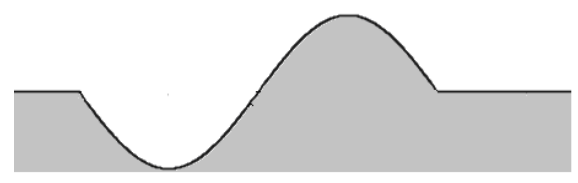

б)

Рис. 2. Відскок колеса на перешкоді (а), геометрія перешкоди (б)

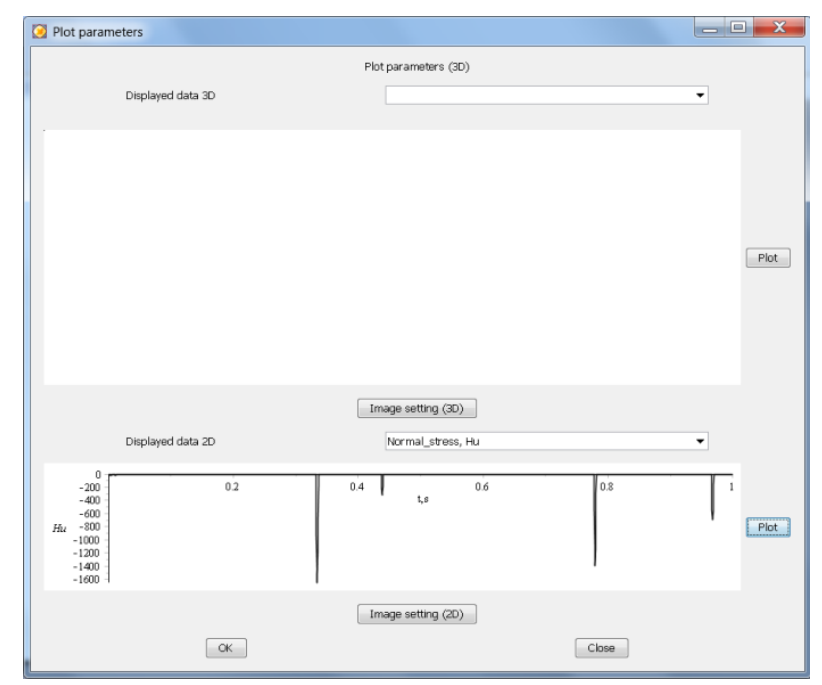

Рис. 3. Відповідні ударні напруги в умовних одиницях на дорожньому покритті при відскоках колеса

Значення жорсткості шини взяті з [5-7] як перерахований уявний модуль пружності 60000 H/M². Ударні навантаження не дають можливості прослідити за коливальними процесами в шині.

Прослідити коливання шини під навантаженням можливо, якщо перешкода буде більш повільною, або буде менше швидкість автомобілю. Такий приклад наведено нижче (рис.4).

В якості перешкод було змонтовано три ролики діаметром 60 мм на хрестовому двокоординатному столі. «Перешкоду» змінювали конструктивно (рис.5):

- три ролики поруч з мінімальним зазором - «рівна поверхня»;

- середній ролик відсутній - «невелика яма»;

- перший ролик вище за інших - «бугор». 


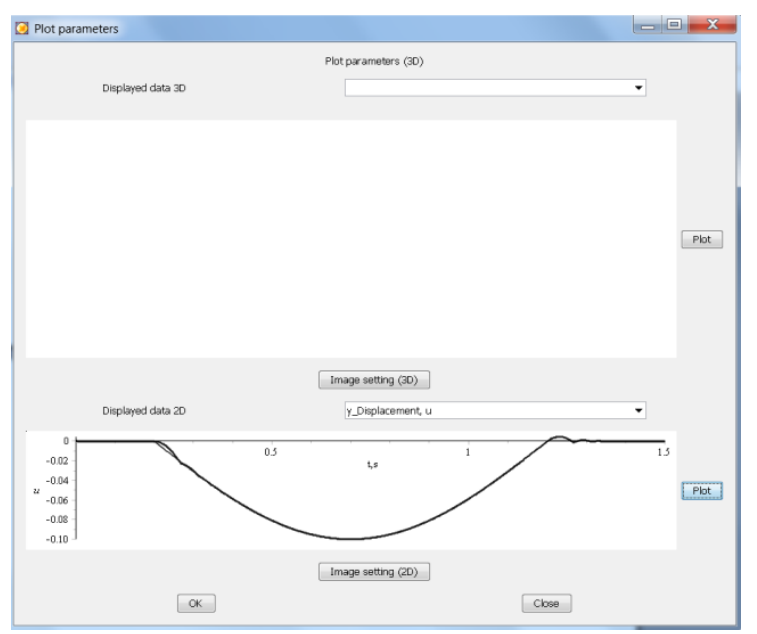

a)

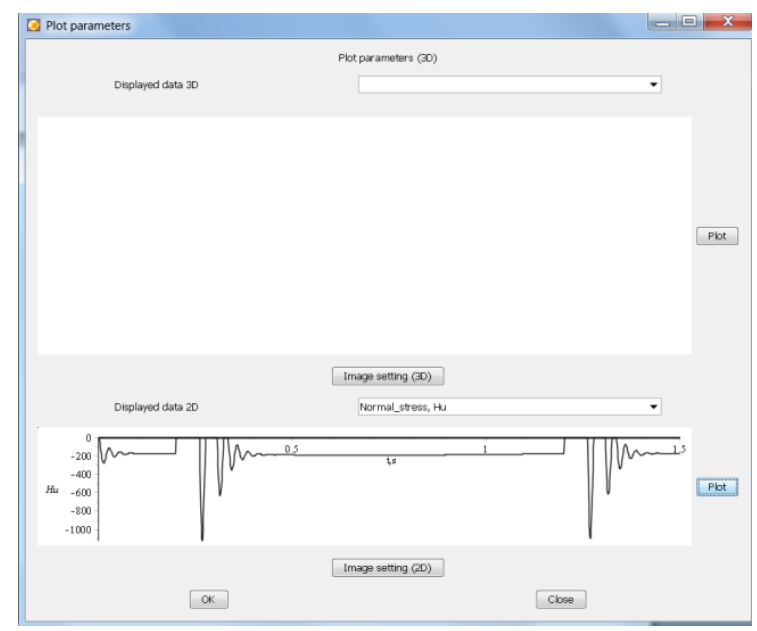

б)

Рис. 4. Приклад подолання увігнутої внутрішньої перешкоди (а) із значенням коливань шини (б)

Колесо навантажувалось стрижневою системою зверху чотирма приводами 3 кроковими двигунами [6]. Величина навантаження задавалась у вигляді відстані від вільного радіусу колеса до лінійного уздовж радіусу переміщення платформи 3 колесом, яке складало до 40 мм при різних контрольованих значеннях внутрішнього тиску. Для дистанційного зняття деформації шини використано комп'ютеризовану вимірювальну головку 3 цифровим відліковим пристроєм INTELLIGENT МІКРОТЕХ® ( виробник м. Харків) з можливістю передачі вимірювань по системі блютуз в процесі руху (обертання) колеса на перешкоді.

На бічну поверхню шини було нанесено сітку і під час опускання колеса проводилось записування відеотреку з подальшою «розкадровкою» і накладанням сіток одна на другу. Даний експеримент було проведено в статиці для трьох значень внутрішнього тиску в шині : 1 Атм, 1,5 Атм, 2 Атм.

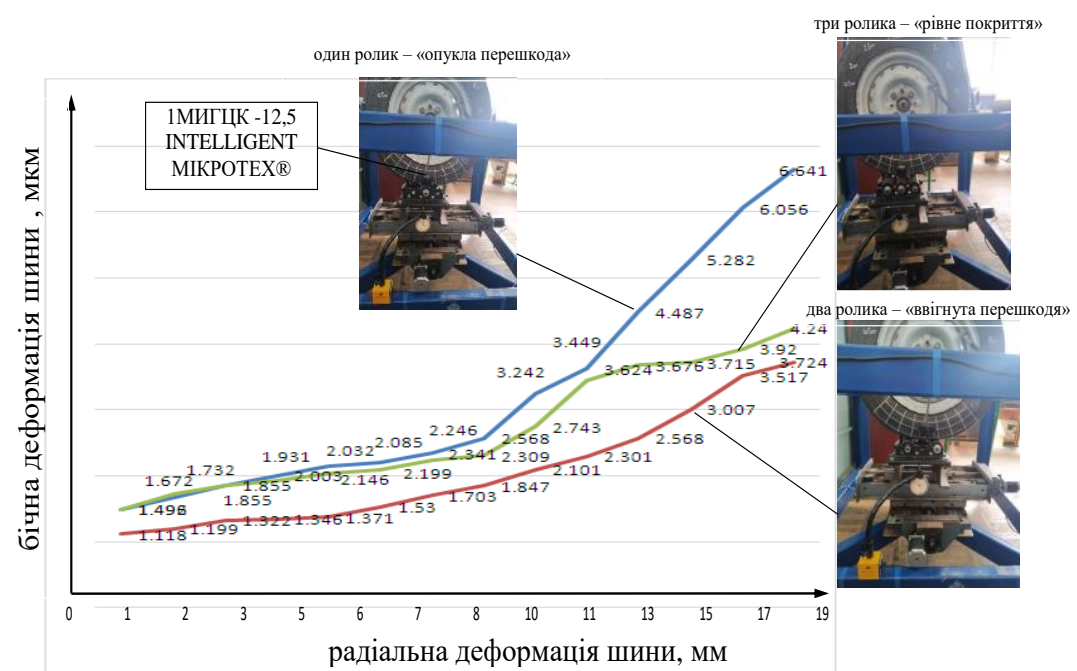

Рис. 5. Залежність ступеню бічної деформації шини від типу і геометрії перешкоди (тиск 1 Атм)

Розроблювана методика може стати альтернативою суто теоретичному визначенню реакцій колеса і шини на різноманітні перешкоди, в різних умовах руху автомобіля і дії зовнішніх факторів. Наприклад, лише змодельованим процесам методом скінчених елементів (рис. 6, а) можна протиставити дані, які отримано експериментально, на багатокоординатному стенді для випробування шин, як режим низькополігонального редагування сітки модифікаторами (Edit Mash, Bend, Push, Skew і ін.) середовища 3dStudio MAX з можливістю анімації усіх керованих параметрів (рис.6, б). 


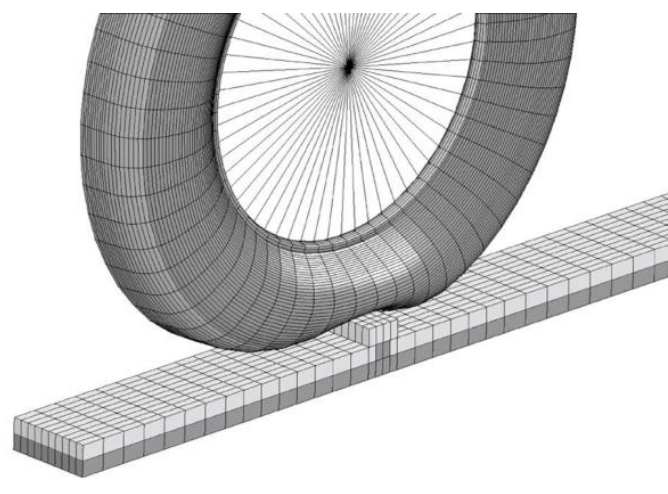

a)

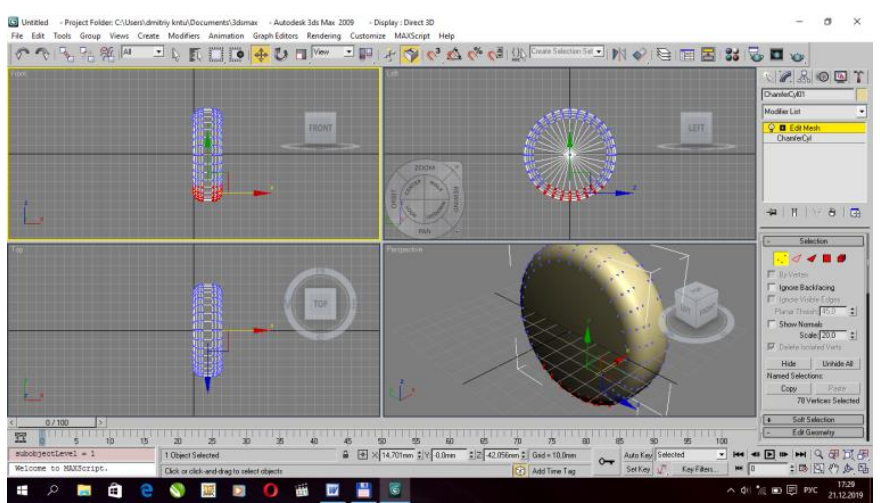

б)

Рис. 6. Моделювання деформованого стану шини при перекочування через нерівність:

a) методом скінчених елементів в САЕ - системах;

б) методом управління геометрією шини з урахуванням феноменологічного підходу в середовищі 3dStudioMAX

Особливістю програмного середовища 3dStudio MAX є відкритість програмного коду MaxScript, що дозволяє створювати окремі прикладні програми і модулі для управління (відтворення) саме тих місць і видів деформації шини, які відповідають конкретним умовам руху і видам перешкод. Основні модифікатори геометрії показано на рис.7.

Змінні, що входять в розрахунок отримують дані про сітку деформації з експерименту i транслюють власні значення в математичні залежності стандартних модифікаторів геометрії без врахування сил, швидкостей і навантажень, що повністю відповідає процесу моделювання і спрощує отримання візуального відтворення подолання перешкоди автомобілем.

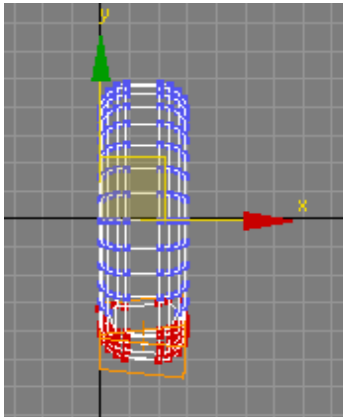

a)

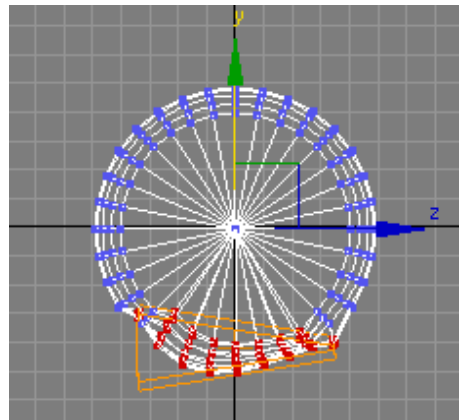

б)

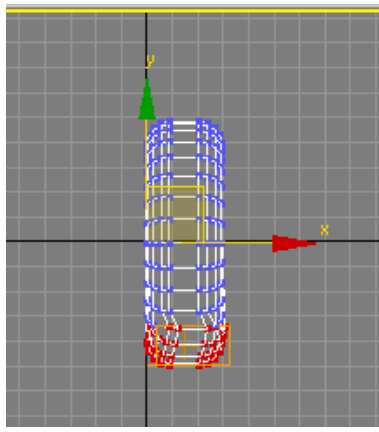

в)

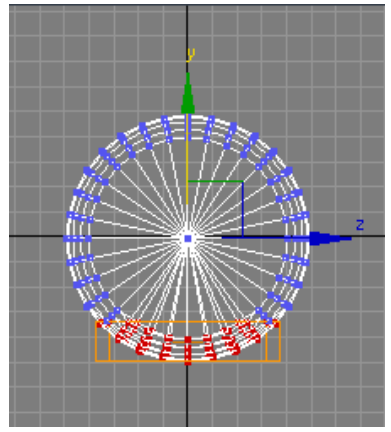

г)

Рис. 7. Приклад роботи модифікатора Bend

Таким чином, можна задавати будь-які комбінації деформування шини, вираховувати швидкість змін точок колеса як морфінг (перетикання) еластичної оболонки з одного стану в другий.

Напрямки подальших досліджень: удосконалення механічної складової випробувального стенду, зокрема, щодо підвищення потужності приводів для реалізації більших навантажень і швидкостей механічного впливу на пошкоджуваність шин; захист вимірювальних засобів від відцентрових, ударних, коливальних, i інших збурень для забезпечення коротких вимірювань деформацій шини в динаміці; створення багатоканальної системи зчитування характерних точок на ділянці деформування шини; створення системи передачі даних про механо-кінематичні властивості шини під час випробування на кшталт Motion Capture Technology (захват руху) для більш оперативної оцінки процесів, що відбуваються 3 шиною під час подолання перешкод.

\section{Висновки}

Запропоновано, змонтовано i проведено тестові випробування (силові i вібраційні) на багатокоординатному стенді з просторовим розташуванням приводів для відтворення орієнтації колеса в найбільш наближених до дорожніх умов. Запропоновано технологію моделювання проміжних станів деформації шин i ïx порівняння $з$ ступенем накопичення пошкоджень як деформації ділянок при подоланні перешкод різної геометрії при стендових випробуваннях.

\section{Список використаної літератури}

1. .Механика шины : монография / [В. А. Перегон, В. А. Карпенко, Л. П. Гречко и др.] ; Харьков. 
нац. автомоб.-дорож. ун-т. - Х. : ХНАДУ, 2011. - 403 с.

2. Ключові аспекти взаємодії шини з опорною поверхнею: монографія / [В.В. Біліченко, О.Л. Добровольский, В.М. Ребедайло.] - Вінниця:ВНТУ, 2013. - 128 с.

3. Ларин А.Н., Черток Е.Е., Юрченко А.Н. Колесные узлы современных автомобилей (шины, камеры, диски) / А. Н. Ларин [и др.] ; общ. ред. А. Н. Юрченко. - Х. : С.А.М., 2004. - 260 с.

4. Зінько Р.В., Крайник Л.В., Горбай О.З. Основи констуктивного синтезу та динаміка спеціальних автомобілів і технологічних машин: монографія - Львів: видавництво Львівської політехніки, 2019. $344 \mathrm{c}$.

5. Чурсов С.О. Механіка шин: властивості, безпечність, методи випробування /Войтович О.А. Баль О.Д. // "Сучасні технології промислового комплексу: базові процесні інновації": IV Міжнародна науковопрактична конференція. -ХНТУ: Херсон. - 2018 (с.269-270)

6. Чурсов С.О. Застосування багатокоординатних механізмів в якості випробувальних стендів шин автотранспорту /Чурсов С.О., Дмитрієв Д.О. Войтович О.А. Баль О.Д. //Комплексне забезпечення якості технологічних процесів та систем: VIII Міжнародна науково-практична конференція. - ЧНТУ:Чернігів. 2018.- C.147-149.

7. Чурсов С.О. Стендові методи випробування шин автотранспорту / Дмитрієв Д.О., Войтович O.А., Русанов С.А //Вісник Херсонського національного технічного університету.№ 2(69) (2019) С.39-47

8. Система автоматизованого моделювання продуктів віброкиплячих шарів «Виброслой 1.0». Свідоцтво про реєстрацію авторского права на твір №25051. / С.А.Русанов. - №24961: Заявл. 14.04.2008; Опубл. 24.07.2008.

9. Чурсов С.О. Моделювання механічних характеристик матеріалів пневматичних шин в процесі подолання перешкод. / Дмитрієв Д.О., Русанов С.А //Матеріали IX Всеукраїнської науково-практичної конференції студентів, аспірантів та молодих вчених 3 автоматичного управління присвяченої Дню космонавтики. ХНТУ: Херсон. - 2021.- С (с.89-90)

10. Чурсов С.О. Прогнозування залишкового ресурсу матеріалів пневматичних шин від накопичення і виду експлуатаційних пошкоджень. / Дмитрієв Д.О., Панасенко В.М., Русанов С.А //Матеріали IX Всеукраїнської науково-практичної конференції студентів, аспірантів та молодих вчених 3 автоматичного управління присвяченої Дню космонавтики. ХНТУ: Херсон. - 2021.- С.94-95

\section{References}

1. .Mekhanyka shyny : monohrafyya / [V. A. Perehon, V. A. Karpenko, L. P. Hrechko y dr.] ; Khar'kov. nats. avtomob.-dorozh. un-t. - KH. : KHNADU, 2011. - 403 p.

2. Klyuchovi aspekty vzayemodiyi shyny z opornoyu poverkhneyu: monohrafiya / [V.V. Bilichenko, O.L. Dobrovol'skyy, V.M. Rebedaylo.] - Vinnytsya:VNTU, 2013. - 128 p.

3. Laryn A.N., Chertok E.E., Yurchenko A.N. Kolesnye uzly sovremennykh avtomobyley (shyny, kamery, dysky) / A. N. Laryn [y dr.] ; obshch. red. A. N. Yurchenko. - KH. : S.A.M., 2004. - 260 p.

4. Zin'ko R.V., Kraynyk L.V., Horbay O.Z. Osnovy konstuktyvnoho syntezu ta dynamika spetsial'nykh avtomobiliv i tekhnolohichnykh mashyn: monohrafiya - L'viv: vydavnytstvo L'vivs'koyi politekhniky, 2019. $344 \mathrm{p}$.

5. Chursov S.O. Mekhanika shyn: vlastyvosti, bezpechnist', metody vyprobuvannya /Voytovych O.A. Bal' O.D. // "Suchasni tekhnolohiyi promyslovoho kompleksu: bazovi protsesni innovatsiyi": IV Mizhnarodna naukovo-praktychna konferentsiya. -KHNTU: Kherson. - 2018 - pp.269-270)

6. Chursov S.O. Zastosuvannya bahatokoordynatnykh mekhanizmiv v yakosti vyprobuval'nykh stendiv shyn avtotransportu /Chursov S.O., Dmytriyev D.O. Voytovych O.A. Bal' O.D. //Kompleksne zabezpechennya yakosti tekhnolohichnykh protsesiv ta system: VIII Mizhnarodna naukovo-praktychna konferentsiya. CHNTU:Chernihiv. - 2018.- pp.147-149.

7. Chursov S.O. Stendovi metody vyprobuvannya shyn avtotransportu / Dmytriyev D.O., Voytovych O.A., Rusanov S.A //Visnyk Khersons'koho natsional'noho tekhnichnoho universytetu.№ 2(69) (2019) pp.39-47

8. Systema avtomatyzovanoho modelyuvannya produktiv vibrokyplyachykh shariv «Vybrosloy $1.0 »$. Svidotstvo pro reyestratsiyu avtorskoho prava na tvir №25051. / S.A.Rusanov. - №24961: Zayavl. 14.04.2008; Opubl. 24.07.2008.

9. Chursov S.O. Modelyuvannya mekhanichnykh kharakterystyk materialiv pnevmatychnykh shyn $\mathrm{v}$ protsesi podolannya pereshkod. / Dmytriyev D.O., Rusanov S.A //Materialy IX Vseukrayins'koyi naukovopraktychnoyi konferentsiyi studentiv, aspirantiv ta molodykh vchenykh z avtomatychnoho upravlinnya prysvyachenoyi Dnyu kosmonavtyky. KHNTU: Kherson. - 2021.- pp.89-90

10. Chursov S.O. Prohnozuvannya zalyshkovoho resursu materialiv pnevmatychnykh shyn vid nakopychennya i vydu ekspluatatsiynykh poshkodzhen'. / Dmytriyev D.O., Panasenko V.M., Rusanov S.A //Materialy IX Vseukrayins'koyi naukovo-praktychnoyi konferentsiyi studentiv, aspirantiv ta molodykh vchenykh z avtomatychnoho upravlinnya prysvyachenoyi Dnyu kosmonavtyky. KHNTU: Kherson. - 2021.pp.94-95 